\title{
Correction: Laccase activity of the ascomycete fungus Nectriella pironii and innovative strategies for its production on leaf litter of an urban park
}

\author{
Aleksandra Góralczyk-Bińkowska, Anna Jasińska, Andrzej Długoński, \\ Przemysław Płociński, Jerzy Długoński
}

There is an error in affiliation 2 for author Andrzej Długoński. The correct affiliation 2 is: Institute of Biological Sciences, Cardinal Stefan Wyszynski University, Warsaw, Warsaw, Poland.

\section{Reference}

1. Góralczyk-Bińkowska A, Jasińska A, Długoński A, Płociński P, Długoński J (2020) Laccase activity of the ascomycete fungus Nectriella pironii and innovative strategies for its production on leaf litter of an urban park. PLoS ONE 15(4): e0231453. https://doi.org/10.1371/journal.pone.0231453 PMID: 32298310

\section{G openaccess}

Citation: Góralczyk-Bińkowska A, Jasińska A, Długoński A, Płociński P, Długoński J (2020)

Correction: Laccase activity of the ascomycete fungus Nectriella pironii and innovative strategies for its production on leaf litter of an urban park. PLoS ONE 15(5): e0233553. https://doi.org/ 10.1371/journal.pone.0233553

Published: May 14, 2020

Copyright: ๑ 2020 Góralczyk-Bińkowska et al. This is an open access article distributed under the terms of the Creative Commons Attribution License, which permits unrestricted use, distribution, and reproduction in any medium, provided the original author and source are credited. 